ISSN: p. 2354-354X e. $2354-3515$

Open Access Journal, Available Online

\title{
Crisis Communication and Ghana's Financial Sector
}

\author{
${ }^{1}$ Fortune Tella, ${ }^{2}$ Alidu Suraya, ${ }^{3}$ Modesta A. Bonsu \& \\ ${ }^{4}$ Albert A. Anani-Bossman \\ ${ }^{1,2,3}$ Christian Service University College, Kumasi, Ghana. \\ ${ }^{4}$ Pentecost University College, Accra, Ghana \\ ftella@csuc.edu.gh
}

Received: 7 April 2020 Accepted: 19 May 2020 Date of Publication: June 2020

Abstract: This study explores the place of crisis communication in Ghana's financial sector. It identifies and analyzes the various approaches that practitioners adopted to save the country from the brink of disaster a few years ago. In-depth interviews with eight public relations consultants and evidence from literature show stakeholders' dissatisfaction with the communication strategies implemented by some financial institutions. The combination of reactive/proactive and leadership communication/provocation approaches to managing the crises produced both positive and negative outcomes. Findings also show that if practitioners have the requisite knowledge and training as well as operate from a department wholly dedicated to public relations, crisis communication can produce the desired effect. The effectiveness can increase if the top management of the financial institutions gives the necessary support to the department. Ghana's crisis is proof that not recognizing public relations officers as central role players during a crisis can escalate the crisis rather than lessen it.

Keywords: Crisis, crisis communication, organizations, financial institutions, public relations, communication management. 
Introduction

Crises pose threats to people and organizations (Coombs, 2010). A crisis can cut off the expectations of stakeholders (Heath, 2010) and undermine the integrity of a business. Customers lose trust even as the reputation of the organization ebbs. The Global financial crises of 2008 posed severe challenges for banks and other institutions in the financial services sector, such as mortgage credit institutions and mutual fund companies (Fredriksson, 2014). According to Mitchell (2017), the crisis is regarded as the worst economic downturn since the Great Depression in the 1930s. The crisis brought many economies to the brink of financial turmoil. Most developed and emerging markets suffered the effects beyond the United States, where it originated from (Mitchell, 2017).

The Global financial crises of 2008 posed severe challenges for banks and other institutions in the financial services sector, such as mortgage credit institutions, mutual fund companies, and other financial institutions (Fredriksson 2014). According to Mitchell (2017), the 2008 financial crisis is regarded as the worst economic downturn since the Great Depression in the 1930s. The crisis brought many economies to the brink of financial turmoil. Despite originating from the U.S., most developed and emerging markets suffered the effects (Mitchell 2017).

Ghana has had its share of financial crises in the last three years. The financial services sector went through severe financial challenges and crises between 2017 and 2019. The Bank of Ghana implemented regulatory reforms at the beginning of 2017 to clean up the banking sector and strengthen the operations of financial institutions in Ghana (PwC, 2019). The reforms led to the total number of banks being reduced from 34 to 23 (PwC, 2019). Eleven banks exited the sector, including the five that were declared insolvent ( $\mathrm{PwC}$, 2019).

The five banks, namely UniBank Ghana Limited (UGL), The Beige Bank (TBB), and The Royal Bank Limited (TRB), Sovereign Bank Limited (SBL), and The Construction Bank Limited (TCB) had their licenses revoked. The reasons for the revocation include low capital funds, high levels of NonPerforming Loans (NPLs), suspicious and non-existent capital, corporate governance gaps, poor management, and poor credit analysis of customers (PwC, 2019; Amuakwa-Mensah \& BoakyeAdjei, 2015). The Ghanaian Minister of Finance, Mr. Ken Ofori-Atta, is reported to have said that the cost of the reforms to the government and taxpayers is estimated between $\$ 3$ billion and 
\$4 billion (Ghana Joy Business, 2019).

The Bank of Ghana reforms shook the confidence of many customers and stakeholders of banks. The financial sector is heavily dependent on the trust of investors and customers. As a result, information regarding financial services and operations is considered essential by customers and stakeholders. Stakeholders of financial institutions look forward to receiving information from these institutions, particularly in times of a financial crisis. The way crisis information is handled and managed contributes immensely to the restoration of normalcy and reputation for organizations (Zuzak \& Konigova, 2009, p. 50-55). Effective crisis management can potentially strengthen stakeholders' trust and enhance the reputation of organizations (ŠontaitePetkeviciene, 2014, p.4531; Motarjemi, 2014, p.1053). How an organization uses communication before, during, and after a crisis is vital in determining the organization's ability to recover from the crisis (Zaremba, 2010). Communication failures during crises pose a danger to stakeholders (Lanard \& Sandman, 2014; Levinson, 2014; McKay, 2015).

\section{The Problem Statement}

Many of Ghana's financial institutions wounded up between 2017 and 2019. During the dissolution, several frustrated customers lamented the inadequate or lack of accurate information on their savings and investments. The Central Bank of Ghana, Securities, and Exchange Commission (SEC) and the affected financial institutions were accused of leaving them in the dark (Dodoo \& Simons, 2018; Sasa, 2018). There were no clear directives to customers on the actions to take to recover their losses (Ayitey, 2019). Some customers expected the Ghanaian government to provide information on steps put in place to secure their investments (Sasa, 2018; Ayitey, 2019). Customers and other stakeholders also expressed angst at the communication approaches and messaging of these financial institutions during the crisis. Some of these institutions were criticized for poor customer relations and inadequate response to crises. Those criticisms were visible in the cases of the Midlands Savings Loans Company press statement in connection with an assault on a customer by a police officer; and the Menzgold Company's directive to customers on repayment schedules for customers' funds (Graphic.com, 2018; Sasa, 2018). 
Many of these criticisms targeted the public relations departments of the financial institutions as $\mathrm{PR}$ practitioners were denounced for not doing enough in using communication to respond to issues stakeholders considered crucial. Mensah (2018) points out that practitioners should have, on behalf of their institutions, engaged and explained to stakeholders, the role their institutions played in the crisis. The need to engage with the customers existed, but that need was not satisfied.

The lack of trust by stakeholders in organizational communication during and after a crisis is a challenge the Ghanaian financial sector must adequately manage. The approach to communication management during a crisis seems to be weak and not strategic. It appears that in some of these financial institutions (mainly banks), public relations officers are not considered part of the core decision-makers during crises. The need to ascertain the nature and approach to crisis communication management within the financial services industry of Ghana elicited this study.

\section{Research Questions for the Study}

In order to ascertain how communication is handled and managed in crises associated with the financial services sector of Ghana, the following research questions were set for the study:

1. What communication approaches do Ghanaian financial institutions use during a crisis?

2. How effective are the communication approaches deployed by Ghanaian financial institutions in the management of crisis?

\section{Review of Literature}

Crisis and Crisis Situations

Crises generate interactions, information exchanges, and engagements between organizations and stakeholders. A crisis is explained as "a specific, unexpected and non-routine event or series of events that create high levels of uncertainty and threatens an organization's high - priority goals" (Seeger et al. 2012, p.33).

The concept of crisis has been described generally as unpredictable and dangerous (Austin, Lin \& Jin 2012; Fearn Banks 2011; Baron, 2010). For example, Sellnow et al. (2013) describe a crisis as an event that is characterized by threat, surprise, and limited time for response. The 
way a crisis is handled and managed contributes immensely to the restoration of normalcy and reputation to the organization (Zuzak \& Konigova, p. 2009, p.5055). Effective crisis management can potentially strengthen stakeholders' trust and enhance the reputation of organizations (Petkeviciene, 2014, p.4531; Motarjemi, 2014, p.1053).

\section{Crisis Management}

When a crisis hits an organization, measures must be adopted to lessen the damage from the crisis (Coombs, 2015). The concept of crisis management is visible in literature. Crisis management "seeks to prevent or lessen the negative outcomes of a crisis and thereby protect the organization, stakeholders, and the industry from harm" (Coombs, 2015). Crisis management strategies can potentially strengthen stakeholders' trust and enhance the reputation of organizations (Petkeviciene, 2014, p.453; Motarjemi, 2014, p.1053).

One crucial strategy in crisis management is the use of communication. The inability to communicate effectively during a crisis can be fatal for organizations (Lanard \& Sandman, 2014; Levinson, 2014; McKay, 2015). Villines (2011, p.10) points that crisis management includes crisis communication - acquiring and publicizing information. Fearn-
Banks (2016, p.2) explains crisis communication as a communication plan that is designed to enable organizations to manage potential crises and actual crisis events, and involves gathering and disseminating crisisrelated information to stakeholders.

Crisis management strategies, when deployed, are purposively geared towards protecting the reputation of the organization. The attainment of corporate goals and credibility recognition is dependent mainly on reputation (Lattimore, Baskin, Heiman \& Toth 2012, p.362). According to Coombs \& Holladay (2008), crisis response messages that provide instructive information result in higher postcrisis reputation evaluation. Furthermore, organizations that show concern in their crisis responses are perceived more favorably (Dean, 2004). That is why the subject of crisis communication is critical in the crisis management process.

\section{Crisis communication}

Crisis communication is explained as involving a communication plan that seeks to ensure that an organization is well-positioned to manage potential and actual crises and events, includes gathering and disseminating crisis-related information to stakeholders (FearnBanks, 2016 p.2). 
Patashnick (2016, p.15) asserts that crisis communication is a decision of top management. Simons (2014) points out that there are two broad categories in crisis communication, thus, managing information and managing meaning. The management of information involves collecting, analyzing, and disseminating information during a crisis. The management of meaning has to do with using messages in an attempt to shape how people perceive the crisis and the organization facing the crisis (Simons, 2014). When stakeholders are adequately informed about the crisis management efforts deployed by the organization, stakeholders are reassured that the organization is trustworthy, and the organization can also achieve something positive for its reputation.

\section{The Issue Reputation}

Reputations have become a critical resource and concern for organizations (Ikpefan et al., 2020). Therefore, the need for every organization to have a positive reputation cannot be overemphasized. Organizations with good reputations can attract customers, investment, motivate employees, attract top employees, and ultimately have improved financial performance (Davies, Chun, da Silva, \& Roper, 2003). Reputation is how stakeholders perceive an organization (Roberts
\& Dowling 2002; Fombrun \& Van Riel, 2004). Coombs (2010) asserts that reputations are created through direct and mediated contact with an organization - where direct experience includes buying a product, visiting a store, or using a service. Mediated contact has to do with messages from the organization, (word - of - mouth communication, online messages, and the like) as well as news media coverage about the organization. All the various points of contact with an organization are fused in a stakeholder's mind to create a mixture that is the organization's reputation (Coombs, 2010).

2.5The Ghanaian banking crisis: the role of practitioners in the crisis resolution

Ghana's financial sector has, in recent times, faced numerous financial challenges (Cann, 2017). Cann (2017) submits that key financial indicators such as capital adequacy ratio, liquidity ratio, and non-performing loans (assets) of some financial institutions in Ghana deteriorated to unacceptable levels. He adds that the most reasonable solution was to declare these institutions as insolvent. The Bank of Ghana implemented some measures to bring sanity to the financial sector. At the end of the implementation of the measures, two banks, Capital Bank and UT Bank, were liquidated in 2017 and 
five others (BEIGE Bank, Sovereign Bank, Construction Bank, UniBank, and Royal Bank) were declared insolvent in 2018. The insolvent banks were later combined and brought under the banking umbrella known as Consolidated Bank Ghana (CBG) (Benson 2019). Key findings from KPMG's report on the situation indicated severe corporate governance, risk management, compliance, and management flaws, as well as unlawful transactions involving shareholders related parties and connected parties.

In 2019, the Bank of Ghana revoked the licenses of 386 financial institutions. These include 347 microfinance companies and 39 microcredit companies (Ibrahim, 2019). The Bank of Ghana stated that the licenses had been revoked as a result of poor lending culture and risk management systems, poor governance practices, and undercapitalization (Ibrahim, 2019). The Governor of the Bank of Ghana intimated that the core objective of the exercise was to stabilize the financial industry and protect the funds of depositors (Ibrahim, 2019).

Reactions to the actions of the Bank of Ghana were both positive and negative. Public relations practitioners of these institutions were expected to play critical communication roles to manage the crises. Public relations academics and professionals agree that the best way to deal with a crisis is to be proactive (Schmitz, 2009). Hussaini and Mohammed (2008) assert that the proactive mode of public relations approach means the ability of public relations to anticipate problems ahead of time and put measures in place to solve them correctly. Igben (2008) refers to this same process as preventive public relations, thus, taking action ahead of time. Amodu (2011, p.118) states that "an organization's skill in handling itself amid crises will have a bearing on the way its various publics perceive it for years to come." Heath \& Millar (2004, p.6) also acknowledge that a proactive approach to communication can help an organization satisfy two functions: a search for possible crises and ways of mitigating the crises when they occur, and second, an organization is put in readiness to manage a crisis. Effective crisis communication management is essential for protecting the reputation of financial institutions. Reputation is a valuable asset, and a crisis can threaten it. It is the responsibility of $\mathrm{PR}$ practitioners to protect the reputation of their organizations (DiStaso, 2010). 
Theoretical Framework

The study's theoretical foundation is supported by James Grunig's excellence theory propounded in 1984. This theory focuses on ensuring effective and efficient public relations practice. The excellence theory provides a descriptive and prescriptive role of public relations in strategic management (Kim, HungBaesecke, Yang \& Grunig, 2013, p.198). The theory provides a framework on how public relations should be structured and practiced. The theory characteristically is designed to enable public relations to:

- contribute to the attainment of organizational objectives through the application of strategic decision-making processes

- operate independently as a department and separate from other departments

- run on a program designed to achieve public relations goals

- rely on skills and competencies that can help public relations practitioners to be successful with their craft

- apply different communication models to engendering positive stakeholder relationships

- value relationships and seek the commitment of the dominant coalition towards integrating stakeholder relationships in the planning and evaluation of public relations programs ((Kim et al., 2013).

The excellence theory suggests that if public relations can help build sustainable relationships with key stakeholders, then public relations is effective (Grunig, Grunig \& Ehling, 1992, p.86). The theory helps to anchor this study because it advances the need for public relations to be used and managed strategically. If public relations practitioners participate in strategic decision-making activities of an organization, the role of the public relations department towards organizational goals will be useful. The public relations department will be well-positioned to design programs that value organizationstakeholder relationships (Kim et al., 2013, p.202).

As described in sections 1.1 and 2.5 , respectively, of this study, the public relations departments and officers of financial institutions were criticized for lack of efficiency and effectiveness in crisis communication. The theory argues that excellent public relations allows practitioners to be strategic with communication and also independent in program design and implementation. When the public relations department operates independently, 
communication functions are well coordinated.

The two-way symmetrical model is strongly emphasized in the excellence theory (Dozier, Grunig \& Grunig, 1995). Fearn-Banks (2010:2) asserts that organizations stricken by crisis must dialogue with stakeholders. The dialogue must be directed towards information awareness and exchange so that both the organization and stakeholders benefit. As two-way symmetrical communication is designed to ensure mutual understanding between organizations and stakeholders, applying the excellence theory to this study is relevant. The excellence theory, if supported and applied, can ensure communication excellence. Public relations must get the dominant coalition of the organization to endorse its approach to excellent communication. As the dominant coalition directs strategy in the organization, practitioners must seek the support of top management in public relations and communication initiatives (Dozier et al., 1995; Amodu et al., 2019; Odiboh et al., 2017). Swart (2010) adds that the dominant coalition's support can enable practitioners to identify issues that potentially can become a crisis. Practitioners can then educate and counsel the dominant coalition on ways for managing and engaging with stakeholders.

The theory is useful for crisis communication management as it is in line with public relations practice at the strategy level. This can prove useful to organizations primarily in crises. Top management will be prepared to support crisis communication strategies geared towards engendering positive organization-stakeholder

relationships and organizational reputation.

\section{Methodology}

The study adopted the qualitative approach, which enabled the researchers to explore and gather in-depth information on the crisis communication approaches of public relations practitioners working in the financial services sector of Ghana. Qualitative research approach explores and seeks to understand the meaning individuals or groups ascribe to a social or human problem (Creswell, 2013 p.5). The process of research involves emerging questions and procedures, data typically collected in the participants setting, data analysis inductively building from particulars to general themes, and the researcher making interpretations of the meaning of the data (Creswell, 2013, p.5). 
Sampling

The target population includes financial institutions operating in Ghana. In the context of the study, financial institutions include banks and savings and loan companies. Based on the researchers' judgment (Denscombe, 2010, p.24-25), the availability sampling method was adopted in selecting the public relations practitioners working in the financial sector of Ghana and picked public relations consultants with expertise in crisis communication and reputation management. The selection of the consultants was to help in providing an independent view of crisis communication management in the financial services sector.

Similarly, the availability sampling system was implemented to select four public relations practitioners working for four top financial institutions in Ghana, namely: GCB Bank, Barclays Bank, Stanbic Bank, and Sinapi Aba Savings \& Loans Ltd. The first three banks are among the top five banks in Ghana, with the largest market share in 2018 (PwC, 2019, p.47). Sinapi Aba Savings and Loans Ltd is one of the savings and loan companies declared by the Bank of Ghana as in good standing (Ibrahim, 2019). The use of the purposive sampling technique also allowed for the selection of four public relations consultants knowledgeable

in crisis communication and reputation management. A purposive sample method refers to "the deliberate selection of specific individuals, events or settings because of crucial information they provide that cannot be obtained so well through other channels" Liamputtong (2013, p.14). Thus, a total number of eight (8) public relations practitioners were selected for the study. The four PR officials interviewed are the heads or deputy heads of public relations of their organizations. Their educational backgrounds are a mixture of public relations and marketing.

\section{Data collection}

The data for this study was gathered through the use of the semi-structured interview method. A semi-structured interview approach allowed the researchers to use pre-determined questions. This allows for a discussion to commence while the room is created for the researcher to pose further questions that emanate from responses given by participants (Rule \& John, 2011, p.65).

\section{Analysis and Findings}

Crisis events that threatened the reputation of the financial institutions

Participants were asked if they have ever experienced a crisis that threatened the reputation of their 
organizations. Except for one participant, all the other respondents indicated that their organizations had experienced crisis events that threatened the reputation of their organizations. Most of the participants stated that the crisis events range from events that have minimal impact on the reputation of the organization to events that are serious and potentially harmful to the reputation of the organization.

The study also sought to find out from participants the nature of the crisis. The nature of the crises includes media misrepresentation of the organization and staff misconduct and financial malfeasance. A participant intimated that some of the crisis events were biased media reportage that created an unfavorable image about his organization. One participant mentioned that a staff of the organization took monies from customers and failed to deposit the monies into the bank's treasury. The participant had this to say:

Another issue is during the Christmas period of 2018, a staff of the bank collected monies from customers of the bank, and she failed to pay the monies into the treasury of the bank. It became a huge issue around Christmas- there were about 200 people who had given her their monies. People got very worried whether their money was safe and all that - it became something we needed to deal with.

\section{Communication approaches in} managing crisis

This aspect of the study focused on finding out the communication approaches the organizations used in managing a crisis. Participants interviewed gave different views on their approach to communicating in times of crisis. Among the approaches include the deployment of a crisis communication management team that is expected to execute a reactive communication strategy, proactive strategy, bolstering, and leadership communication. A participant whose organization deploys a reactive communication strategy stated:

The plan is that whatever happens if there is a crisis that affects us, our image and reputation, our managing director will be part of it, our communications director will be part of it, some key persons in the $\mathrm{PR}$ department will be part of it and other operations, people. Depending on the kind of situation, then we devise a strategy on how to address it.

Another approach involves leadership communication, which involves the head of the 
organization, taking up the lead role. According to a participant:

The bank has to speak in one voice. We have a crisis management plan, and the plan is clear on who assumes the role of the spokesperson in crisis situations. Usually, the CEO is the lead person on strategic crisis issues such as relationship building and reputation management. Other key officers of the bank also contribute to the crisis communication strategies of the bank any time there is a crisis.

Another participant stated that they sometimes leverage the goodwill they have as a result of their corporate social responsibility initiatives. This serves as a bolstering strategy that enables the organization to enhance its crisis communication efforts during crisis events.

One participant described his organization's approach to crisis communication as proactive. $\mathrm{He}$ said:

I believe that some principles must guide every crisis situation. One is preparation, so preparation means that you have anticipated the risk in your environment, and you would have put in place certain mitigating measures. You know what you are going to do if the crisis hits. Sometimes you get the impression that people are reacting by the minute- they would be better served if they had anticipated and better planned for the situation. The responses, the big one again in the middle of every communication, is how you build credibilitycredibility is driven by two principal pillars- expertise and trustworthiness. And so those are very important to us that in even tough conversations, we make sure that there is no doubt in our credibility and we do that by ensuring we remain very open, transparent and truthful even when it does not immediately appear to inure to our benefit.

One participant described his organization's approach as 'localization.' He explained that when a crisis hits a branch of the bank, the crisis is managed within the local branch, and exposure of the crisis to the media and other relevant stakeholders is avoided. He intimated that such an approach protects the operations of the organization in other geographical locations. He adds that a team is constituted and sent to the branch to engage with crisis victims and establish ways of mitigating the crisis. He, however, admits a lack 
of strategic focus in the crisis communication approach of the organization. He stated:

I think that we are not proactive enough generally as PRs, and then when a crisis does happen, most of the time I think that its management is a little bit all over the place, not structured. I think that we shouldn't be rushed by the media, we should have some kind of a laydown procedure, and expect in the worst-case scenariowhat do you do?

The views of PR experts and consultants interviewed for the study are mainly critical of the lack of understanding and knowledge by these organizations of the vital role of public relations in communication management. They stated from experience, and on some public relations projects that they implemented on behalf of some financial institutions, the top hierarchy is usually focused on financial costs rather than reputational costs. One participant asserted that:

Mostly, because the management of organizations don't have much of an idea of what PR entails and that serves as a setback for practitioners in their effort to manage crises, so until that changes, their contribution would be quite minimal...

Involvement of leadership in effective crisis communication management

A practical communication approach is keen on the management of crises (Coombs, 2010). Top management can play a critical role in ensuring an effective approach to crisis communication. The spearheading efforts of leaders in the attainment of goals, including communication goals, can ensure that organizational stakeholder relationship works (Ruben \& Giglioti 2017, p.17). In crises, leadership is critical in the management efforts to contain the crises (Zerfass, Tench, Vercic, Verhoeven \& Moreno, 2014). Participants were asked whether top management provides the necessary support in the crisis communication efforts of the PR department. All the participants (PR practitioners) agreed that CEOs and other top directors provided the necessary support to ensure effective communication. One participant pointed out that:

They provide us support in many respects; oneavailability, because typically in such conversations you want it to be led from the top, that's when your chief executive and your other executives can be extremely handy. 
Beyond availability, is also the willingness of top management to apply themselves to best communication strategies, because when it comes to communication, everyone who has found himself in school believes that they are God's gift to communication and that may sometimes make it very difficult for practitioners. Let me say that we are blessed with the management that recognizes the professionalism of the team and is open to giving us the professional space to be able to do our job well, and so that is also a big plus.

Another participant indicated that:

The PR outfit of this bank gets much support from the CEOs office and other key management members. The PR office submits its communication plan, including a crisis communication plan annually to the CEOs office. The plans are scrutinized, and suggestions are put across by the CEO for the effective implementation of a crisis communication strategy. Management also supports the PR office to attend training and seminars associated with strategic communication practice.
Crisis communication

planning

A practical approach to crisis communication involves planning. Crisis planning is an approach designed to enable the crisis team, communication, and other crisis management activities effective in producing good crisis management outcomes (Wang \& Ritchie, 2012). Participants (both PR officers of the financial institutions and PR consultants) agree that an effective approach to crisis communication is the use of a crisis communication plan. Two participants representing two of the financial institutions stated that they have a crisis communication plan. One participant acknowledged the value of a crisis communication plan, particularly for financial institutions:

Having a plan has enabled the PR team to strategize appropriately and be effective in dealing and managing a crisis. The plan contains information on communication strategies specific to crisis situations and stakeholders. We even have pre-drafted messages that guide us on our approach to communicating during a crisis event. Our crisis communication planning has helped us a lot to minimize damage to the reputation of our company. 
The view of another participant (PR consultant) on crisis communication planning is that:

As a PR consultant, I will tell you that financial institutions should have put measures in place even before the crisis. Of course the loss of money, revenue, been affected by the macroeconomic situations is something that banks should pre-empt before they take people's monies; therefore, they should have put together strategies to avert some of these before they even assume crisis proportions and if there is anything, I think that the people involved should be told. Therefore in managing crises, you don't allow things to degenerate before the people who gave you their trust would know. So for me, I don't believe in managing crises when the issues have blown up, but I think that they should have been nipped in the bud before they assume crisis situations.

\section{Expertise in crisis}

\section{communication management}

As emphasized earlier in this study, customers of financial institutions that were declared insolvent expressed displeasure at the communication strategy of these institutions. Mensah (2018) also criticized the PR officers of these institutions for not engaging effectively with victims of the financial crisis. Thus, in this aspect of the study, the researchers set out to establish the crisis communication expertise of participants. All participants working for the financial institutions intimated that they have the required skills set in crisis communication. Some participants said they were skilled in issues mapping, stakeholder mapping, messaging strategies, crisis radar, and reputation management. One participant stated:

I have, over the years, acquired relevant experience in crisis communication and reputation management. I have had the opportunity to manage and coordinate crisis communication efforts. It has not always been rosy and a walk-in-thepark managing crisis events, particularly in the financial services sector. There have been challenges, especially in stakeholder engagement. But my expertise and ability to lead my team have helped in mitigating crises. I understand the importance of pre-crisis, crisis, and post-crisis planning. My team and I regularly update our knowledge in crisis communication management. 
The PR consultants were generally in agreement with the views on crisis communication expertise expressed by the PR officers. A participant acknowledged that though some PR practitioners have the expertise in crisis communication, the organization's interests more often than not are put first instead of the interests of the affected stakeholders:

Of course, the expertise exists, but usually, a crisis is managed from the organization's perspective rather than the people who are affected, and that makes it a little less effective because if you take another person's interest into view, the crisis would have been well managed. But all in all, or in most instances, you realize that it's managed from the organization's benefits or interests. Therefore, in the end, they don't attain any benefits because the people who are affected are still affected, which shouldn't be so.

One participant was, however, not impressed with the crisis communication expertise of some PR practitioners. He argued that the public relations course curriculum taught in some universities in Ghana do not offer a comprehensive insight into crisis communication management:
Again, I will say to some extent it does, but it's also limited as I said because looking at a number of the communication schools even coming up, not all of them even teach crisis communication, so a lot of them (trained PR practitioners) come out without much knowledge in crisis communication, and so sometimes they tend to be more reactive; sometimes they tend to go the way of management by not paying serious attention to crises or denying the existence of a crisis - instead of taking responsibility and ensuring that the organization takes responsibility. So to some extent, there is the expertise, but it is also limited by our understanding of crisis management and PR practice in general in Ghana.

Assessment of Crisis

Communication during the

Financial Sector Crisis

The financial industry in Ghana recently faced crises. The thoughts of participants were investigated to determine how the industry managed the various crises with communication and whether participants were satisfied with the approaches used. Participants (consultants) expressed divergent views on the communication approached deployed by the 
affected financial institutions. Two of the participants expressed dissatisfaction that the institutions reacted late in engaging with victims of the financial crisis and showed apathy towards communicating strategically. One participant stated:

The financial sector didn't manage the crisis well. The financial issues were thrust into the public domain at the last minute when nothing could be done about them. When people could not get access to their funds from the banks, we all didn't understand what was happening. There were panic withdrawals because there were speculations and rumors that the banking sector was collapsing. Some people withdrew all their monies, and those people who could not withdraw looked forward to some form of communication from the institutions, and most of the affected institutions failed to provide relevant and adequate information to affected customers. The newspapers published most of the issues, and the radio stations took up the stories. It was more like a two-step flow information. Then most of them embellished it; most of them interpreted the information, particularly in their newspaper readership segment. That one caused much fear amongst the public and worry. I think it was not well managed by the PR practitioners, their organizations, and the industry regulators.

The other participant blamed the financial institutions' inability to be effective with communication on the exclusion of PR officers from high-level decision making. $\mathrm{He}$ stated that PR officers of some of the financial institutions are only called to sit in management meetings and have an attendance mark and not allowed to advise on matters such as reputation and communication management. $\mathrm{He}$ also asserted that his recent research on $\mathrm{PR}$ practice in the financial sector of Ghana revealed that a significant number of $\mathrm{PR}$ managers have backgrounds in other social science disciplines other than public relations and communication. He argued that if people manage public relations practice with no or limited exposure to public relations and communication training, then ensuring crisis communication effectiveness will be a challenge.

The two other participants held the view that the financial crisis was more of a regulatory problem 
than a communication problem. One participant pointed out that: What happened in the financial sector, they are crisis, yes, but one would ask to what extent can communications resolve it. These are regulatory issues. Bank of Ghana is supposed to regulate these banks, and they are supposed to meet certain things, and so the Bank of Ghana realizes that some number of banks have not maybe followed due process, and then they say we want to take certain measures like maybe collapse some of the banks. Some of those measures they are regulation issues; it is not every crisis that is a communication issue per se even though communication can help to resolve, and then it is not the individual banks that were really handling it.

\section{Discussion of Findings}

This study provided insights into how public relations officials working in the financial institutions of Ghana approach communication during crisis events. Additionally, our study sought to establish the effectiveness of the various approaches used by public relations managers working for these institutions. From the various responses gathered, our study shows that participants' approaches to crisis

communication management differ from one another. The selected institutions dealt with their various crises through the use of both internal and external communication. The PR officials of the institutions pointed out that in their line of operations, they encounter crises that have either minimum or maximum impact.

This study assessed the crisis communication approaches used by PR officers of selected Ghanaian financial institutions, and it emerged that PR officers used reactive, proactive leadership communication, and provocation approaches.

The use of reactive strategies to contain or manage a crisis may not be effective in managing the information expectations of customers. Stakeholders look forward to instantaneous, transparent, clear, and comprehensive information in times of crisis (Schanz 2009, p.263). The confidence customers and other stakeholders have in an organization can be severely dampened if the organization is unable to manage the crisis effectively (Weber, Erickson \& Stone 2011, p.37). Customers commit to a financial relationship with financial institutions based on trust and confidence (DiStaso, 2010). When customers lose these fundamental values in their banks, 
they begin to view those banks with suspicion, cynicism, and disappointment (DiStaso, 2010). Crises come with chaos and confusion. If communication has not been planned for, the public relations managers' communication reactions on behalf of their organizations will likely not be executed in ways that satisfy the information needs of customers and stakeholders. Our position on the reactive approach to crisis communication is that it is not adequate, and there are chances that practitioners who use this approach can come under much pressure and emotional outbursts of customers and other stakeholders.

Proactive approaches enable practitioners to have in place a plan. As emphasized by one participant, a proactive approach to crisis communication allows his financial institution to prepare, anticipate, and better manage a crisis. Crisis victims and other stakeholders expect organizations to engage with them. A proactive approach enables openness and cooperation (Slabbert \& Barker, 2011, p.445). Organizations that want to win the trust and confidence of stakeholders need to be proactive in their crisis communication approach. Benoit and Pang (2008, p.252) acknowledge that a proactive approach can enable organizations to avoid mistakes and reduce response time to crises. Additionally, proactive crisis communication can help organizations to avoid crises altogether (Bloom, 2008).

Some participants alluded to the importance of leadership in their approach to crisis communication. Leaders are expected to be influencers, interpreters of situations, negotiators, and debaters of views (Gold et al., 2016). Additionally, leaders must promote effective communication within their organizations (Gundersen, Hellesoy \& Raeder 2012; Meng \& Berger, 2011). When organizations encounter crises, the leaders of the response provide must be appropriate to improve stakeholder confidence in the organization (Coldwell, Joosub \& Papageorgiou, 2012). Organizational leaders must provide inspired leadership. Undoubtedly, the involvement of organizational leaders in the crisis effort, particularly satisfying the information needs of customers and other stakeholders, can strengthen and make the crisis communication efforts of public relations practitioners effective.

The use of provocation can be both positive and negative during a crisis. Organizations must be well guided in using the crisis response approach of provocation. According to Benoit (1995), 
provocation is when an organization assumes a position based on the actions of another party (Benoit, 1995). Public relations practitioners must be cautious in applying measures that alienate their organizations from essential stakeholders such as the media. For instance, a participant argued that the media could be blamed for aggravating crises as the media sometimes have an agenda to tarnish the reputation of the organization. The criticism of the media role must be handled effectively. The media are active interpreters of crises, and they can positively or negatively influence perceptions (Greve et al., 2010; Wiersem \& Zhang, 2013). When a crisis hits, the media are active in creating initial awareness and also framing the narrative surrounding the crisis (Neuwirth, 2010; Schultz et al., 2012). Organizations must have a crisis communication approach centered on first satisfying the information needs of stakeholders, particularly crisis victims (Coombs, 2007). The media can play essential roles in serving as channels that deliver crisis relevant information to stakeholders.

Even though there are different motives in the use of these approaches, the communication effort must result in strategic communication. Strategic communication involves communication processes that are planned with the view to ensure the attainment of organizational goals (Falkenheimer \& Heide, 2014b). Crisis communication is strategic if it is planned before the onset of a crisis and ends when normalcy is restored, and satisfaction is achieved (Palttala \& Vos, 2012). Ghanaian PR officers of financial institutions need to approach crisis communication with strategic communication intent. A strategic communication approach creates communication opportunities with stakeholders. If stakeholders are left on their own to make sense of the crisis without the strategic intervention of the organization, stakeholders will find it challenging to understand the position of the organization (Vander Meer et al., 2017, p.435).

\section{Conclusion}

This study has some implications for crisis communication and the expected roles of public relations practitioners. First, this study highlighted the subject of top management support. Participants asserted that their CEOs supported their crisis communication management efforts. Leaders must motivate their communication managers to work towards positive communication outcomes, especially in crises. When 
communication managers have the support of the heads of their organizations, they will be confident and committed to implementing a crisis communication program that revolves around strategic communication.

Second, our study provides an insight into a communication management phenomenon described by a participant as 'localization.' This communication approach involves taking strategic measures to restrict access to crisis information by key external stakeholders. Crisis information is made available to only crisis victims and critical internal staff of the organization. The reasoning behind this strategy is to limit or prevent maximum publicity of the crisis. However, in the era of social media, this approach is not sustainable. Stakeholders, including crisis victims and the media, can frame crisis communication on social media, and their actions can further aggravate the crisis. The localization approach lacks a strategic communication focus. Public relations practitioners must be allowed to apply the right strategies with stakeholders when managing a crisis (Kleinnijenhuis et al., 2015).

Thirdly, our study revealed that some of the participants interviewed have qualifications and backgrounds that are not public relations-oriented. These revelations by some participants could be the reason why public relations consultants who participated in this study stated that some organizations lack the expertise to implement a crisis communication strategy effectively. A recent study on public relations practice in the Ghanaian banking sector revealed that out of the 22 public relations managers interviewed, $36 \%$ have MBA in Marketing, and only $9 \%$ have MA/MPhil in Corporate Communication. Other participants have master's degrees in luxury management, marketing communication, among others (Anani-Bossman 2019, p.180). Anani-Bossman (2019, p.273) asserts that the marketing background of some of these public relations managers in the financial services sector influenced how public relations is practiced in these organizations. Some of these managers conceptualize public relations in terms of marketing and publicity (Anani-Bossman 2019, p.273). The consequences of such conceptualization of public relations could result in minimal attention to strategic communication and dialogic communication; and weak organizational-stakeholder relationship. Public relations 
managers or officers must be people with requisite qualifications and experience in public relations.

Finally, most public relations functions are subsumed under other departments, such as marketing (Anani-Bossman 2019, p.270). A public relations unit/department must handle public relations programs and activities. As strongly advocated by Grunig (1992) in his Excellence Theory, for public relations practice to be excellent and strategic to the goals of an organization, public relations must be a single department; public relations functions must not be integrated with other departments. As stated in the introduction section of this study, customers of Ghanaian financial institutions that were declared insolvent by the Bank of Ghana expressed dissatisfaction with the communication approach of these institutions (Dodoo \& Simons, 2018; Ayitey, 2019; Mensah, 2018). If communication is used symmetrically and geared towards both the interests of stakeholders and the organization and not necessarily to support the marketing function, the customer crisis communication experience will be better. Slabbert and Barker (2011, p.451) argue that if communication is fully utilized as a management function, crisis communication will add significant value to the operations of organizations.

\section{Recommendations}

Based on the findings, we recommend the following:

- The public relations departments of the financial services sector must be empowered and wellresourced to effectively manage a crisis.

- The management of crisis within the financial services sector must be approached proactively.

- Public relations officers working in the financial services sector must look beyond regulatory measures and get the top hierarchy to endorse the curation (i.e. collecting, selecting, and presenting) of crisis information.

- Public relations officers must be confident in deploying crisis communication strategies. Crisis victims must be provided with information on the crisis. They and other stakeholders must be provided with information that enables them to cope with the psychological effects of a crisis and uncertainty. 
Limitations and directions for future research

This study has some limitations, including the number of study participants. As a result of the size of the study participants, the results of our study cannot be generalized to represent the population of public relations working in financial institutions. Also, only one savings and loan company was considered for the study. The views expressed by the participant from the savings and loans do not represent the population of savings and loan companies in Ghana. The outcome of this study does not extend to other financial services categories, such as investment houses and discount houses.

\section{References}

Amodu, L.O. (2011). Public Relations: The art and social science crisis management. Mass

Communication-A Book of Readings, pp. 110-124.

Amodu, L., Omojola, O., Okorie, N., Adeyeye, B \& Adesina, E. (2019). Potentials of Internet of Things for effective public relations activities: Are professionals ready? Cogent Business \& Management, 6:1, DOI: 10.1 080/23311975.2019.1683951
Despite these limitations, our findings provide a good understanding of how public relations practitioners approach crisis communication.

Further research can be quantitative in approach and could assess the views of public relations practitioners working in all the categories of financial services in Ghana. Other researchers can explore into actual crisis communication challenges that the insolvent banks faced. Future research can also look into crisis communication on social media and the role expected of public relations practitioners in the financial services sector.

Amuakwa-Mensah, F. \& BoakyeAdjei, A. (2015). Determinants of nonperforming loans in Ghana banking industry. International Journal of Computational Economics and Econometrics, 5(1), pp.3554.

Anani-Bossman, A. (2018). Developing framework for public relations practice: a study of the financial services sector in Ghana. (Doctoral 
dissertation). Pretoria: University of South Africa Austin, L., Fisher Liu, B. \& Jin, Y. (2012). How audiences seek out crisis information: Exploring the socialmediated crisis communication

model. Journal of Applied Communication

Research, 40(2), 188-207.

Ayitey, C. (2019). Banking Consultant calls for stricter banking reforms to avert future crisis. Myjoyonline. Retrieved November 22, 2019, from https://www.myjoyonline.co m/business/2019/march27th/banking-consultantcalls-for-stricter-bankingreforms-to-avert-futurecrisis.php.

Baron, G. (2010). Response suggestions and public participation the new norm in response management. Crisis Comm. Retrieved December 12, 2018, from http://www.emergencymgmt. com/emergency-blogs/ crisis-comm/ResponseSuggestions-and-Public111510.html.

Barton, L. (2001). Crisis in organizations II. Cincinnati: South-Western Publishing, College Learning.

Thomson
Barton, L. (1994). Preparing the marketing manager for crisis: The use and application of new strategic tools. Marketing Intelligence and Planning, 12 (11): 41-46.

Baxter, J., \& Bartlett, P.L. (2001). Infinite-horizon policygradient estimation. Journal of Artificial Intelligence Research, 15, 319-350.

Benoit, W.L. \& Pang, A. (2008). Crisis communication and image repair discourse. Boston: Pearson Allyn \& Bacon.

Benoit, W.L. (1995). Accounts, excuses, and apologies: A theory of image restoration strategies, SUNY series in speech. Albany: State University of New York Press.

Benson, E. (2019). Bank Failure in Ghana: What Accounted for the Collapse

Unibank? (Doctoral dissertation).

Accra: University of Ghana, Legon.

Bloom, E. (2008). Crisis readiness and disaster communication: Disaster management. Enterprise Risk, 2(3), 26-27.

Cann, J.P. (2017). The Collapse of UT Bank Ltd and Capital Bank Ghana Ltd - Root Cause Analysis. Retrieved December 2, 2019, from 
https://www.linkedin.com/pu lse/collapse-ut-bank-ltdcapital-ghana-root-causeanalysis-cann/

Coldwell, D.A.L, Joosub, T. \& Papageorgiou, E. (2012). Responsible leadership in organizational crises: An analysis of the effects of public perceptions of selected SA business organizations'

reputations. Journal of Business Ethics, 109(2), 133144.

Coombs, W.T. (2015). Ongoing Crisis Communication: Planning, Managing and Responding. Thousand Oaks (CA): Sage Publishing.

Coombs, W.T. (2014). Ongoing crisis communication: Planning, managing, and responding. Thousand Oaks (CA): Sage Publishing.

Coombs, W.T., \& Holladay, S.J. (Eds.). (2011). The handbook of crisis communication (Vol. 22). Boston: John Wiley \& Sons.

Coombs, W.T., \& Holladay, S.J. (2008). Comparing Apology to Equivalent Crisis Response Strategies: Clarifying Apology's Role and Value in Crisis Communication. Public Relations Review, 34, 252257.
Coombs, W.T. (2007). Protecting Organization Reputations during a Crisis: The Development and Application of Situational Crisis Communication Theory. Corporate Reputation Review, 10(3), 163-177.

Creswell, J.W. (2013). Research Design: $\quad$ Qualitative, Quantitative, and Mixed Methods Approaches. Thousand Oaks, CA: SAGE Publications.

Davies, G., Chun, R., Da Silva, R.V., \& Roper, S. (2003). Corporate Reputation and Competitiveness. New York: Routledge

Dean, D.W. (2004). Consumer reaction to negative publicity: Effects of corporate reputation, response, and responsibility for a crisis event. Journal of Business Communication, 41, 192-211.

Denscombe, M. (2010). The good research guide for smallscale social research projects. Fourth Edition. England. Open University Press, McGraw-Hill Education.

DiStaso, M.W. (2010). Industry in crisis: The communication challenge in the banking 
industry. Public Relations Journal, 4(1), pp.1-17.

Dodoo, A. \& Simon, B. (2018). Ghana Banking Crisis Cleaning financial sector through standards. Retrieved December 11, 2019, from .https://www.myjoyonline.co $\mathrm{m} /$ opinion/2018/october-

10th/ghana-banking-crisiscleaning-the-financial-sectorthrough-standards.php.

Dozier, D. \& Grunig, L., Grunig, J.G. (1995). Manager's guide to excellence in public relations and communication management. Mahwah NJ: Lawrence Erlbaum.

Falkheimer, J. \& Heide, M. (2010). Crisis communicators in change: From plans to improvisations. Handbook of crisis communication, pp.511-526.

Fearn-Banks, K. (2016). Crisis communications: A casebook approach. New York, NY: Routledge.

Fearn-Banks, K. (2011). Crisis communications: A casebook approach. New York, NY: Routledge.

Fearn-Banks, K. (2010). Crisis Communication: A casebook approach. London: Taylor \& Francis.

Fombrun, C.J. \& van Riel, C.B.M. (2004). Fame and Fortune: How Successful Companies
Build Winning Reputation. New Jersey: Pearson Education.

Fredriksson, M. (2014). Crisis communication as institutional maintenance. Public Relations Inquiry, 3(3), 319-340.

Graphic Online. (2018). Midland Savings and Loans apologizes to brutalized customer. Graphic Online. Retrieved November 13, 2018, from https://www.graphic.com.gh/ news/general-news/midlandsavings-and-loansapologises-to-brutalisedcustomer.html.

Greve, H.R., Palmer, D., \& Pozner, J.E. (2010). Organizations gone wild: The causes, processes, and consequences of organizational misconduct. Academy of Management Annals, 4(1), 53-107

Grunig, L.A, Grunig, J.E. \& Ehling, W.P. (1992). What is an effective organization? Excellence in public relations and communication management, pp.65-90.

Gundersen, G., Hellesøy, B.T., \& Raeder, S. (2012). Leading international project teams: The effectiveness of transformational leadership 
in dynamic work environments. Journal of Leadership \& Organizational

Studies, 19(1), 46-57.

Heath, R.L., \& Millar, D.P. (2004).

A Rhetorical approach to crisis communication: Management, communication processes, and strategic responses. In D. P. Millar \& R.L. Heath (Eds.), Responding to crisis: A rhetorical approach to crisis communication (pp. 117). Mahwah, New Jersey: Lawrence Erlbaum Associates.

Heath, R.L., \& O'Hair, H. D. (Eds.) (2010). Handbook of risk and crisis communication. New York: Routledge.

Hussaini, A., \& Mohammed, S. (2008). Public relations and conflict management. In Mojaye, E. M., Arhagba, E., Soola, E. and Oso, L. (Eds). Media, Dialogue, Peace Building and Reconciliation: Conference Proceedings, 6-8 August, 2008 (pp.588-592). Abraka: ACCE, Delta State University.

Ibrahim, A. (2019). Licences of 386 financial institutions revoked. Myjoyonline. Retrieved January 11, 2020, from https://www.myjoyonline.co $\mathrm{m} /$ business/2019/May31st/licence-of-347microfinance-companiesrevoked.php.

Igben, H.G.O. (2008). Public relations, issues and conflict management in Nigeria. In Media, Dialogue, Peace Building and Reconciliation: Conference Proceedings (pp. 602-610).

Ikpefan, O.A., Ibinabo, H., Osuma, G.O., \& Omojola, O (2020). relationship marketing and deposit mobilization in five deposit money banks in Nigeria. Academy of Strategic Management Journal, 18 (6), 1-15.

JoyBusiness. (2019). Full List of licensed Savings and Loans companies as at August 16. Myjoyonline.com. Retrieved December 5, 2019, from https://www.myjoyonline.co $\mathrm{m} /$ business/2019/August17th/full-list-of-licensedsavings-and-loanscompanies-as-at-august16.php.

Kim, J.N., Hung-Baesecke, C.J.F., Yang, S.U., \& Grunig, J.E. (2013). A strategic management approach to reputation, relationships, and publics: The research heritage of the excellence theory. The handbook of communication and 
corporate

pp.197-212.

Kleinnijenhuis, J., Schultz, F., Utz, S. \& Oegema, D. (2015). The mediating role of the news in the BP oil spill crisis 2010: How US news is influenced by public relations and in turn influences public awareness, foreign news, and the share price. Communication Research, 42(3), pp.408-428. Lattimore, D., Baskin, O., Heiman, S.T., \& Toth, E.E. (2012). Public Relations: The Profession and the Practice. New York: McGraw Hill.

Levinson, D.R. (2014). Hospital emergency preparedness response during superstorm sandy. Department of Health and Human Services, Office of the Inspector General, Washington, DC, Retrieved January 15, 2019 from, https://oig.hhs.gov/oei/report s/oei-06-13-00260.pdf.

Liamputtong, P. (2013). Qualitative research methods. Victoria: Oxford University Press.

McKay, J. (2015). Ebola response provides key lessons for risk communications: The CDC fumbled initial communications about Ebola transmission but recovered. What about next time? Retrieved December 5, 2019, from

http://www.emergencymgmt. com/health/Ebola-ResponseProvidesLessons-RiskCommunications.html.

Meng, J., Berger, B.K., \& Heyman, W.C. (2011). Measuring public relations leadership in the trait approach: A secondorder factor model in the dimension of selfdynamics. Public Relations Journal, 5(1), pp.1-24.

Mensah, I.A. (2018). Shylock and the Failed Banks; What PR practitioners should do. Writersghana.com. Retrieved November 28, 2019, from https://www.writersghana.co $\mathrm{m} / 2018 / 08 / 02 /$ shylock-andthe-failed-banks-what-prpractitioners-should-do/.

Motarjemi, Y. (2014). Crisis management. In Food Safety Management, pp. 1037-1063. Cambridge: Academic Press.

Neuwirth, K. (2010). Risk, crisis, and mediated communication. In R. L. Heath, \& H. D. O'Hair (Eds.). Handbook of risk and crisis communication (pp.398-411). New York: Routledge.

Odiboh, O., Omojola, O., Okorie, N., \& Ekanem, T. (2017). Sobotone, Ponkiriyon, herbal marketing communication and Nigeria's healthcare 
system. Proceedings of SOCIOINT 2017- 4th International Conference on Education, Social Sciences and Humanities 10-12 July 2017- Dubai, UAE. Retrieved May 22, 2020 from http://eprints.covenantuniver sity.edu.ng/10098/1/dr\%20o diboh\%20dubai\%202.pdf

Palttala, P., \& Vos, M. (2012). Quality indicators for crisis communication to support emergency management by public authorities. Journal of Contingencies and Crisis Management, 20(1), pp.3951.

Patashnick, M.J. (2016). Social media and crisis communication: Supporting best practice on university campuses.

(Doctoral

dissertation). Pennsylvania: University of Pennsylvania.

PwC. (2019). Ghana Banking Survey. PwC. Retrieved January 5, 2020, from http://www.pwc.com/gh.

Roberts, P.W., \& Dowling, G.R. (2002). Corporate reputation and sustained superior financial

performance. Strategic

management journal, 23(12), pp.1077-1093.

Ruben, B.D. \& Gigliotti, R.A. (2017). Communication:
Sine qua non of organizational leadership theory and practice. International

Journal of Business

Communication, 54(1),

pp.12-30.

Rule, P., \& John, V. (2011). Your guide to case study. Van Schaik: Pretoria.

Sasa, T. (2019). Latest news on Menzgold Ghana 2018 crisis, big plans and payment issues. Retrieved December 20, 2019, from https://yen.com.gh/118403latest-news-menzgold-ghana2018-crisis-big-planspayment-issues.html.

Schanz, K.U. (2009). Maintaining stakeholder trust in difficult times: Some fundamental reflections in light of the credit crisis. The Geneva Papers on Risk and Insurance-Issues and Practice, 34(2), pp.260-270. Seeger, M.W., Sellnow, T.L., \& Ulmer, R.R. (2012). Communication,

Organization, and Crisis. Communication yearbook 21, 231.

Sellnow, T.L., \& Seeger, M.W. (2013). Theorizing crisis communication. New Jersey: John Wiley \& Sons.

Slabbert, Y., \& Barker, R. (2011). An integrated crisis 
communication framework for strategic crisis communication with the media: A case study on a financial services provider. Communicatio, 37( 3), pp.443-465.

Sandman, P. \& Lanard, J. (2014). Commentary: When the next shoe drops-Ebola crisis communication lessons from October. Center for Infectious Disease Research and Policy.

Schultz, F., Kleinnijenhuis, J., Oegema, D., Utz, S., \& van Atteveldt, W. (2012). Strategic framing in the BP crisis; a semantic network analysis of associative frames. Public Relations Review, 38, 97-107.

Šontaitè-Petkevičienè, M. (2014). Crisis management to avoid damage for corporate reputation: the case of retail chain crisis in the Baltic countries. Procedia-Social and Behavioral Sciences, 156, pp.452-457.

Swart, Y. (2010). An integrated crisis communication framework for strategic crisis communication with the media: a case study on a financial services provider. (Doctoral dissertation). University of South Africa, Pretoria
Tench, R., \& Yeomans, L. (2006). Exploring Public Relations. London: Pearson Education. Tiffany, A. (2018). Latest news on Menzgold Ghana 2018crises, big plans and payment issues. Retrieved December 5, 2019 from, https://yen.com.gh/118403latest-news-menzgold-ghana2018-crisis-big-planspayment-issues.html

Van der Meer, T.G., Verhoeven, P., Beentjes, H.W., \& Vliegenthart, R. (2017). Communication in times of crisis: The stakeholder relationship under pressure. Public Relations Review, 2(43), pp.426-440.

Villines, A.N. (2011). Communicating During Crisis: A Case Study of the 2010 BP Gulf Oil Spill. Retrieved August 20, 2018, from

http://digitalcommons.butler. edu/ugtheses/

Wang, J., \& Ritchie, B.W. (2012). Understanding accommodation managers' crisis planning intention: An application of the theory of planned behaviour. Tourism Management, 33(5), pp.1057-1067.

Weber, M, Erickson, S.L., \& Stone, M. (2011). Corporate reputation management: 
Citibank's use of image restoration strategies during the US banking crisis. Journal of Organizational Culture, Communications and Conflict, 15(2), p.35.

Wiersema, M.F., \& Zhang, Y. (2013). Executive turnover in the stock option backdating wave: The impact of social context. Strategic

Management Journal, 34(5), pp.590-609.

Zaremba, A.J. (2010). Crisis Communication: Theory and Practice. ME Sharpe.
Zerfaß, A., Tench, R., Verčič, D., Verhoeven, P., \& Moreno, A. (2014). European communication monitor 2014: excellence in strategic communication-key issues, leadership, gender and mobile media: results of a survey in 42 countries. BrusselsEACD/EUPRERA, Helios Media9783942263276.

Zuzák, R. \& Königová, M. (2009). Krizové ř́zení podniku [Crises management of a company]. Praha: Grada Publishing. 